\title{
Assessment of the Microbial Diversity of Spent-Oil Contaminated Soil in Calabar, Nigeria
}

\author{
A. A. Unimke ${ }^{1^{*}}$, A. O. Mmuoegbulam ${ }^{1}$, I. U. Bassey ${ }^{1}$ and S. E. Obot ${ }^{1}$ \\ ${ }^{1}$ Department of Microbiology, Faculty of Biological Sciences, University of Calabar, P.M.B. 1115, \\ Calabar, Cross River State, Nigeria.
}

\section{Authors' contributions}

This work was carried out in collaboration between all authors. Author AAU designed the study, performed the statistical analysis, wrote the protocol and wrote the first draft of the manuscript. Authors IUB and AOM managed the analyses of the study. Authors AAU and SEO managed the literature searches. All authors read and approved the final manuscript.

Article Information

DOI: $10.9734 / J A M B / 2017 / 34847$

Editor(s):

(1) Satarupa Dey, Microbiology Laboratory, Department of Botany, University of Calcutta, Kolkata, India. (2) Graciela Castro Escarpulli, Laboratorio de Bacteriologia Medica, Instituto Politécnico Nacional, Mexico.

Reviewers:

(1) Omoregbee Osazuwa, University of Benin, Nigeria. (2) Kohji Ishihara, Okayama University of Science, Japan. Complete Peer review History: http://www.sciencedomain.org/review-history/20114

Original Research Article

Received $15^{\text {th }}$ June 2017

Accepted $2^{\text {nd }}$ July 2017

Published $19^{\text {th }}$ July 2017

ABSTRACT

This study was designed to assess the total heterotrophic and hydrocarbon oxidizing microbial diversity, determine the physicochemical parameters of oil contaminated soil and evaluate the potentials of microorganisms isolated to utilize spent oil. Three mechanic workshops within Calabar South axis of Cross River State Nigeria were selected and three soil samples were collected from each site. The total heterotrophic bacteria were enumerated on nutrient agar and the hydrocarbon utilizing bacteria on minimal salt medium using the vapor phase method after employing the ten-fold dilutions from $1: 10$ to $1: 100000$. The total heterotrophic mean count ranged from $1.28 \times 10^{4}$ to $3.58 \times 10^{4} \mathrm{cfu} / \mathrm{g}$ while mean count of hydrocarbon utilizing bacteria varied from $1.94 \times 10^{4}$ to $7.34 \times 10^{4}$ $\mathrm{cfu} / \mathrm{g}$. Physicochemical parameters of samples were determined. Such parameters included $\mathrm{pH}$, electrical conductivity and compounds such as nitrate, nitrite, phosphate, calcium, magnesium and potassium. The bacterial isolates evaluated belonged to the genera of Bacillus, Klebsiella, Proteus, Pseudomonas, Enterococcus, Flavobacterium and Micrococcus spp. Klebsiella spp. emerged as the most prevalent heterotrophic bacteria with $29.41 \%$ while Bacillus spp, and Enterococcus spp. were 
the least prevalent with 11.77\%. Among the hydrocarbon utilizing bacteria, Pseudomonas flourescens was the most prevalent species with $53.85 \%$ while Micrococcus spp. was the least with $15.39 \%$. Amongst the 3 different sites studied, the mechanic workshop at Goldie Street had the highest mean value for both heterotrophic and hydrocarbon utilizing bacteria ranging from $2.52 \times 10^{4}$ to $3.58 \times 10^{4} \mathrm{cfu} / \mathrm{g}$ for total heterotrophs and $3.27 \times 10^{4}$ to $7.34 \times 10^{4} \mathrm{cfu} / \mathrm{g}$ for hydrocarbon utilizers. The findings reveal that there is a high prevalence of certain populations of active indigenous hydrocarbon oxidizing bacteria which can be monitored and enhanced to bring about bioremediation in the study area.

Keywords: Assessment; heterotrophic; hydrocarbon; microorganisms; contaminated.

\section{INTRODUCTION}

The global emphasis on soil health and sustainable food security is persuading oil scientists to consider rehabilitation of degraded lands, especially where oil-contamination limits the use of land. The universal increase in the usage of petroleum products has resulted in the rapid increasing contamination of soil by spent engine oil (SEO) [1-3].

Spent engine oil, otherwise called waste engine oil, is usually obtained after servicing and subsequent draining from internal combustion engines of automobiles and generators by autorepairers. Spillage of SEO such as engine oil, diesel or jet fuel contaminates the natural environment with hydrocarbon. Hydrocarbon contamination of the air, soil and fresh water especially by polycyclic aromatic hydrocarbons (PAHs) attracts public attention because majority of the PAHs are toxic, mutagenic and carcinogenic [1-3] and SEO contain metals such as arsenic, zinc, cadmium and other potentially toxic substances which can seep through different layers of aquifers into the soil and contaminate ground water.

Large amounts of SEO discharged into the environment when motor oil is changed (when subjected to oxygen, combustion gases and high temperature) and disposed indiscriminately into gutters, water drains, open vacant plots and farmlands is a common practice in Nigeria [3-5]. In addition, the oil is also released into the environment from the exhaust system during engine use and due to engine leaks. These petroleum products tend to harden or change the texture of the soil thereby altering the physicochemical properties of the soil, increasing infertility due to the destruction of soil micro-flora and dwindling of agricultural productivity.

Government efforts to monitor, control and regulate indiscriminate disposal of spent lubricating oil onto agricultural lands have proven to be very difficult because of their short life span and paucity of information. Thus, contamination of agricultural ecosystems arising from discharge of petrol oils and grease is more widespread than crude oil pollution.

Different positions exist on methods to speed up the degradation process of petroleum hydrocarbons just as there are different researchers. Bartha and Atlas [4] concluded that the natural degradation process can be accelerated by the addition of deficient nutrients such as nitrogen and phosphorus (biostimulation); others have suggested microbial seeding of oil spills with biological species which have the metabolic capability of oxidizing petroleum hydrocarbon for cell synthesis (bioaugmentation) and the use of physicochemical treatment methods such as incineration, thermal desorption, coker, cement kiln, solvent extraction and land filling. On the other hand, Christofis et al. [5] posited that several agro technical methods including tilling and loosening, watering and addition of organic materials (straw, compost etc) and mineral fertilizer could decrease the contamination level by $30-40 \%$ due to the oxidation of easily degradable petroleum components.

There are many factors which influence biodegradation process and should be monitored. These include temperature, type of soil, nutrients and oxygen availabilities and microorganism concentration on the impacted site. The physical and chemical characteristics of the oil and oil surface area are also important determinants of biodegradation success. Thus, the success of oil biodegradation technology depends on the ability to establish and maintain conditions that favor enhanced oil biodegradation rates in the contaminated environment $[6,7]$.

In Nigeria, particularly Calabar, several mechanic workshops, filling stations and washing bays are 
springing up with most of these workshops being sited close to water bodies and major drainage systems thereby making these water bodies and drainage systems vulnerable to petroleum contamination. Of particular concern is the indiscriminate and careless discharge of oil products particularly used motor oil from these workshops into the nearby water bodies, soil environment and drainage systems [6]. Also the constantly increasing number of automobiles, coupled with the increasing volume of transportation of oil products and the storage of these oil products generally poses a potential threat to the environment in Nigeria. The study of microbial removal of hydrocarbon pollutants from hydrocarbon-contaminated sites would therefore be an essential practice in mitigating some of the environmental and health concerns arising from hydrocarbon contamination in Nigeria [1,8-10]. This research therefore seeks to investigate and evaluate the removal of hydrocarbon contaminants using heterotrophic and hydrocarbon-oxidizing microorganisms.

\section{MATERIALS AND METHODS}

The research basically involved laboratory experiments which were conducted in accordance with standard laboratory procedures.

\subsection{Study Site}

The study site for this research work was Calabar South. Calabar south is a local government area in Cross River State, Nigeria. Its headquarters is Anantigha. It has an area of $264 \mathrm{~km}^{2}$ and a population of 191,630 at the 2006 census. Soil samples were collected from three different mechanic workshops in Palm Street, Goldie Street and Eyo Efam Street.

\subsection{Sample Collection}

Soil samples were collected in a sterile polyethylene bag using a sterile spatula from the edge of a motor oil-stained patch at different locations of each workshop by scooping to about $5 \mathrm{~cm}$. They were immediately transported to the laboratory for analysis. Samples were homogenized and a sub-sample taken to obtain a good representation of the hydrocarbonoxidizing microorganisms required for the study. Physicochemical properties of the soil such as temperature, $\mathrm{pH}$, carbon content, total nitrogen content, conductivity and heavy metals were examined [8].

\subsection{Bacteriological Analysis}

\subsubsection{Culture media}

The media used were minimal basal medium and nutrient agar media. The media were prepared according to manufacturer's specifications. Appropriate grams of the powder were dissolved into $1000 \mathrm{ml}$ of distilled water. The mixture was thoroughly shaken and allowed to boil. It was sterilized by autoclaving at $121^{\circ} \mathrm{C}$ for 15 minutes. After the sterilization, it was allowed to cool at $45^{\circ} \mathrm{C}$ before dispensing into sterile petridishes.

\subsubsection{Determination of total heterotrophic and hydrocarbon-oxidizing microorganisms}

Ten (10) grams of the oil-contaminated soil was suspended in $90 \mathrm{ml}$ of distilled water and ten-fold serial dilutions of the soil samples from 1:10 to $1: 100000$ were carried out. $1 \mathrm{ml}$ of the $10^{-4}$ dilution for each soil samples was plated in triplicate on nutrient agar amended with nystatin $(50 \mu \mathrm{g} / \mathrm{ml})$ to suppress the growth of fungi using pour plate. The nutrient agar plates were incubated at $37^{\circ} \mathrm{C}$ for $24 \mathrm{~h}[7,8]$. The number of viable microorganisms in the sample was calculated from the number of colonies formed.

Aliquots $(1 \mathrm{ml})$ of soil sample suspension were inoculated using the pour plate technique on mineral salt medium $[7,8]$. The medium contains $10 \mathrm{~g} \mathrm{NaCl}, 0.42 \mathrm{~g} \mathrm{MgSO}_{4} .7 \mathrm{H}_{2} \mathrm{O}, 0.29 \mathrm{~g} \mathrm{KCl}$, $0.53 \mathrm{~g} \mathrm{KH}_{2} \mathrm{PO}_{4}, 0.42 \mathrm{~g} \mathrm{NH}_{4} \mathrm{NO}_{4}$, and $15 \mathrm{~g}$ agar in $1000 \mathrm{ml}$ distilled water (adjusted $\mathrm{pH}$ 6.8) for the enumeration of hydrocarbon-oxidizing microorganisms. Spent engine oil soaked in sterile Whatman (No.1) filter paper and placed aseptically in the dish cover served as carbon source. Thus the hydrocarbon was supplied to the inoculums by vapour-phase transfer. The media was made selective for bacteria by adding nystatin $(50 \mu \mathrm{g} / \mathrm{ml})$ and incubated at room temperature for 5 days; emerging colonies were enumerated.

\subsubsection{Isolation, purification and maintenance of pure cultures}

Discrete colonies from the culture plates were randomly picked using a sterile inoculating wire loop and sub-cultured for purification by streaking on nutrient agar plates and incubated at $37^{\circ} \mathrm{C}$ for $24 \mathrm{~h}$. Pure cultures were stored in nutrient agar slants at $4^{\circ} \mathrm{C}$ for further use. 


\subsection{Physicochemical Analysis}

Physicochemical analyses were used to evaluate the physical and chemical properties of the soil including heavy metals $[7,8,11]$. The parameters analyzed included:

\section{$\underline{2.4 .1 \mathrm{pH}}$}

The $\mathrm{pH}$ of the soil sample was determined using a $\mathrm{pH}$ meter (Model: Hach Sensive). The $\mathrm{pH}$ meter probe was inserted into the sample which was dissolved in saline water in a beaker and the reading was taken $[9,10]$.

\subsubsection{Electrical conductivity (EC)}

A conductivity meter (Model: Orion 3 Star) was used. The conductivity meter probe was rinsed with saline water and inserted into a beaker containing the sample in solution and the reading taken [8].

\subsubsection{Determination of compounds}

These compounds include nitrite, nitrate, phosphates, calcium, magnesium and potassium. Before analysis, the soil samples were digested by measuring out one gram of the composite soil into a conical flask. Concentrated nitric acid and hydrochloric acid were then added in the ratio of $1: 3$ respectively. The flask was corked with a foil and placed in the oven at a temperature of $100^{\circ} \mathrm{C}$ for 30 minutes. Distilled water was then added to the sample and allowed to cool before analyzing the sample with a Spectrophotometer [7-10].

\subsubsection{Heavy metal analysis}

The analysis of the following heavy metals were carried out: Nickel, Lead, Cobalt, Iron, and
Manganese. Analysis was done after finely grounding the samples to facilitate the digestion of $1 \mathrm{~g}$ of the sample with perchloric acid and nitric acid $[7,8]$. Heavy metal content of the samples digest was determined using atomic absorption spectrophotometer (Model UNICAM 939).

\section{RESULTS}

\subsection{Microbiological Characteristics of Soil Samples}

\subsubsection{Total heterotrophic bacteria}

In this study, the result represented in Table 1 shows the total heterotrophic bacterial count in the samples from various locations. It is observed that the mechanic workshop located at Goldie Street of Calabar South produced a significantly higher total heterotrophic bacterial mean count ranging from $2.52 \times 10^{4}$ to $2.58 \times 10^{4}$ $\mathrm{cfu} / \mathrm{g}$ while Eyo Efam had the least mean value of heterotrophic count ranging from $1.76 \times 10^{4}$ to $2.35 \times 10^{4} \mathrm{cfu} / \mathrm{g}$. However, the mean count of heterotrophic bacteria in Palm Street ranged from $1.28 \times 10^{4}$ to $2.76 \times 10^{4} \mathrm{cfu} / \mathrm{g}$.

\subsubsection{Hydrocarbon utilizing bacteria}

These were the total number of bacterial species enumerated that had the ability to degrade hydrocarbon, utilizing them as their sole source of carbon. The mechanic workshop on Goldie Street had the highest hydrocarbon utilizing bacteria mean count ranging from $2.27 \times 10^{4}$ to $2.34 \times 10^{4} \mathrm{cfu} / \mathrm{g}$ while the Eyo Efam had the least mean count ranging from $1.98 \times 10^{4}$ to $2.63 \times 10^{4}$ $\mathrm{cfu} / \mathrm{g}$. However, the mean count observed in the mechanic workshop at Palm Street was range from $1.94 \times 10^{4}$ to $2.12 \times 10^{4} \mathrm{cfu} / \mathrm{g}$ as shown in Table 2.

Table 1. Total heterotrophic bacterial count of the three locations

\begin{tabular}{llllll}
\hline Sample location & Sampling point & $\begin{array}{l}\text { Sample 1 } \\
\text { (cfu/g) }\end{array}$ & $\begin{array}{l}\text { Sample 2 } \\
\text { (cfu/g) }\end{array}$ & $\begin{array}{l}\text { Sample 3 } \\
\text { (cfu/g) }\end{array}$ & $\begin{array}{l}\text { Mean } \\
\text { (cfu/g) }\end{array}$ \\
\hline Palm Street & SP1 & $1.41 \times 10^{5}$ & $2.11 \times 10^{5}$ & $3.21 \times 10^{5}$ & $2.24 \times 10^{5}$ \\
& SP2 & $1.03 \times 10^{5}$ & $1.41 \times 10^{5}$ & $1.4 \times 10^{5}$ & $1.28 \times 10^{5}$ \\
Goldie & SP3 & $1.34 \times 10^{3}$ & $2.31 \times 10^{5}$ & $4.6 \times 10^{5}$ & $2.76 \times 10^{5}$ \\
& SP1 & $2.13 \times 10^{5}$ & $4.2 \times 10^{5}$ & $4.37 \times 10^{5}$ & $3.0 \times 10^{5}$ \\
Eyo Efam & SP2 & $3.0 \times 10^{5}$ & $2.75 \times 10^{5}$ & $4.6 \times 10^{5}$ & $3.0 \times 10^{5}$ \\
& SP3 & $2.81 \times 10^{5}$ & $2.1 \times 10^{5}$ & $2.64 \times 10^{5}$ & $2.52 \times 10^{5}$ \\
& SP1 & $2.11 \times 10^{5}$ & $1.45 \times 10^{5}$ & $2.25 \times 10^{5}$ & $1.94 \times 10^{5}$ \\
& SP2 & $1.32 \times 10^{5}$ & $1.3 \times 10^{5}$ & $2.67 \times 10^{5}$ & $1.76 \times 10^{5}$ \\
& SP3 & $1.71 \times 10^{5}$ & $1.91 \times 10^{5}$ & $3.0 \times 10^{5}$ & $2.35 \times 10^{5}$ \\
\hline \multicolumn{4}{c}{}
\end{tabular}




\subsubsection{Identification of Isolates obtained from spent oil contaminated soil}

The isolates were identified morphologically and biochemically and characterized according to the scheme of Bergey's manual of Determinative Bacteriology [11-13]. In totality, different species of bacteria were isolated. The probable heterotrophic bacteria isolated were Pseudomonas spp., Bacillus spp., Klebsiella spp., Proteus mirabilis, Enterococcus faecalis, Flavobacterium spp., and the total hydrocarbon oxidizing bacteria were Bacillus subtilis, Pseudomonas flourescens and Micrococcus spp. The biochemical reactions of the isolates are shown in Tables 3.

\subsection{Frequency of Total Heterotrophic Bacteria and Hydrocarbon Utilizing Bacteria}

A total of 6 heterotrophic bacteria and 3 hydrocarbon utilizers were isolated and characterized. They included: Klebsiella pneumonia, Enterococcus faecalis, Proteus mirabilis, Pseudomonas aeruginosa and Flavobacterium spp., in the percentage of $29.41 \%, 11.77 \%, 17.65 \%, 23.52 \%$ and $5.88 \%$ prevalence respectively for total heterotrophic bacteria while the hydrocarbon utilizing bacteria were Pseudomonas flourescens, Bacillus spp. and Micrococcus spp., in the percentage of $30.76 \%, 53.85 \%, 15.39 \%$ respectively.

Table 2. Total hydrocarbon utilizing bacterial count of the three locations

\begin{tabular}{llllll}
\hline Sample location & Sampling point & $\begin{array}{l}\text { Sample 1 } \\
\text { (cfu/g) }\end{array}$ & $\begin{array}{l}\text { Sample 2 } \\
\text { (cfu/g) }\end{array}$ & $\begin{array}{l}\text { Sample 3 } \\
\text { (cfu/g) }\end{array}$ & $\begin{array}{l}\text { Mean } \\
\text { (cfu/g) }\end{array}$ \\
\hline Palm Street & SP1 & $1.88 \times 10^{6}$ & $5.9 \times 10^{6}$ & $5.4 \times 10^{6}$ & $4.39 \times 10^{6}$ \\
& SP2 & $2.88 \times 10^{6}$ & $1.52 \times 10^{6}$ & $1.4 \times 10^{6}$ & $1.94 \times 10^{6}$ \\
Goldie & SP3 & $9.6 \times 10^{6}$ & $7.3 \times 10^{6}$ & $1.3 \times 10^{6}$ & $6.1 \times 10^{6}$ \\
& SP1 & $2.1 \times 10^{6}$ & $5.9 \times 10^{6}$ & $5.2 \times 10^{6}$ & $4.4 \times 10^{6}$ \\
& SP2 & $5.5 \times 10^{6}$ & $8.6 \times 10^{6}$ & $7.9 \times 10^{6}$ & $7.3 \times 10^{6}$ \\
Eyo Efam & SP3 & $2.84 \times 10^{6}$ & $3.2 \times 10^{6}$ & $3.7 \times 10^{6}$ & $3.2 \times 10^{6}$ \\
& SP1 & $2.28 \times 10^{6}$ & $1.5 \times 10^{6}$ & $2.1 \times 10^{6}$ & $1.98 \times 10^{6}$ \\
& SP2 & $1.52 \times 10^{6}$ & $5.8 \times 10^{6}$ & $3.5 \times 10^{6}$ & $3.6 \times 10^{6}$ \\
& SP3 & $1.01 \times 10^{6}$ & $3.1 \times 10^{6}$ & $4.2 \times 10^{6}$ & $2.77 \times 10^{6}$ \\
\hline \multicolumn{4}{c}{ Sey: cfu/g= colony forming unit per gram, SP = sampling point } &
\end{tabular}

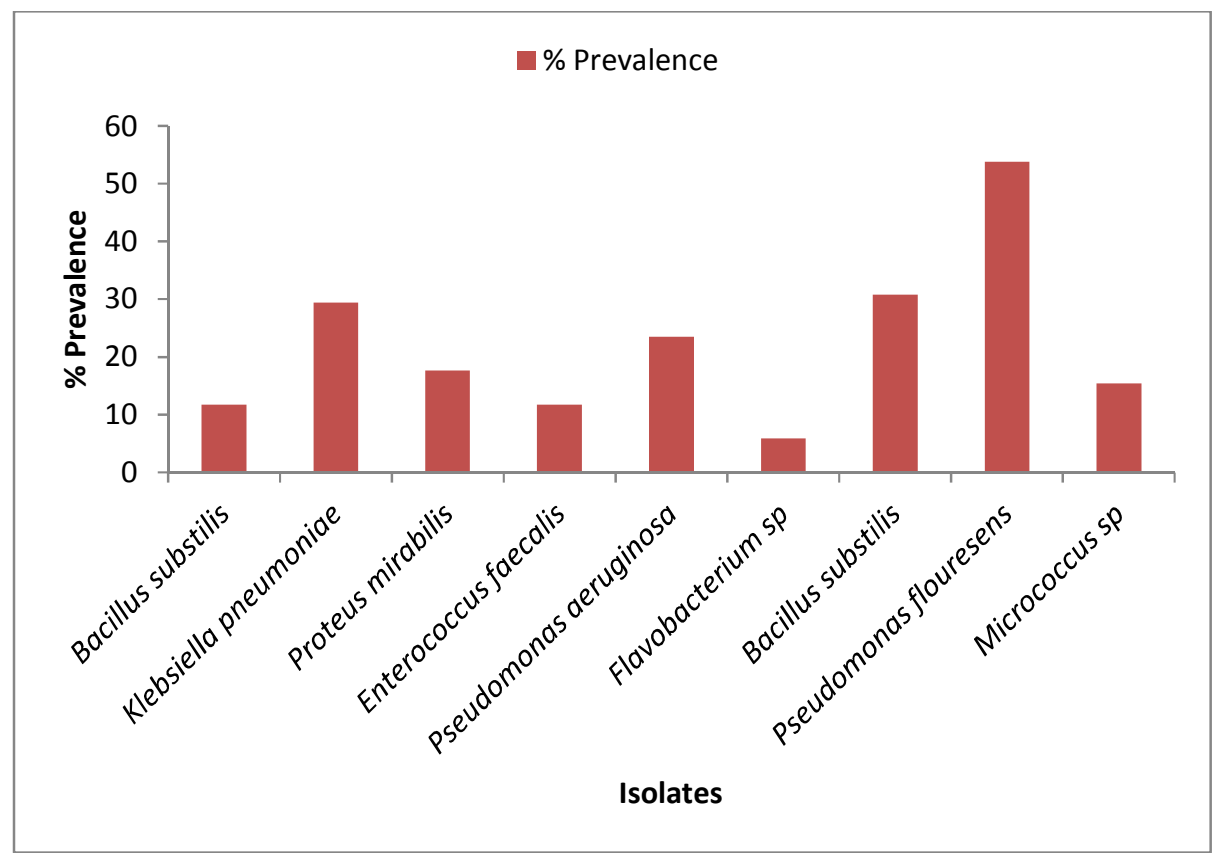

Fig. 1. Percentage prevalence of the bacterial isolates from the different spent-oil contaminated soil samples 


\subsection{Physicochemical Characteristics of Contaminated Soil}

The physiochemical characteristics of composite soil samples collected from different automobile workshops used for the study were analyzed as shown in Fig. 1. Various characteristics like electrical conductivity and $\mathrm{pH}$ were taken into consideration for each of the samples which were named L1, L2 and L3 representing location 1,2 and 3 respectively. From the Fig. 2, it is observed that Location 1 had a relatively basic $\mathrm{pH}$ value of $8.27, \mathrm{EC}$ of $61.3 \mu \mathrm{s} / \mathrm{cm}$, nitrate $283.5 \%$, nitrite $0.19 \%$, phosphate $26 \mathrm{ppm}$ and potassium $24 \mathrm{mg} / \mathrm{g}$. Calcium and magnesium were below detectable level.

Location 2 had a fairly neutral $\mathrm{pH}$ value of 7.67 , EC of $20.6 \mu \mathrm{s} / \mathrm{cm}$, nitrate and nitrite values of
294 and $0.335 \%$, phosphate, calcium and magnesium read $10 \mathrm{ppm}, 0.15 \mathrm{mg} / \mathrm{g}$, and 21 $\mathrm{mg} / \mathrm{g}$ respectively. Magnesium in this location was below detectable level.

Location 3 read for $\mathrm{pH}$ value 7.20, EC 57.9 $\mu \mathrm{s} / \mathrm{cm}$, nitrate and nitrite values of 145 and $0.36 \%$, phosphate level of $26 \mathrm{ppm}$, magnesium and potassium level of 0.05 and $22 \%$ respectively. Calcium value in location 3 was below detectable level.

Heavy metal concentrations and distribution from the three sampling locations is shown in Fig. 2. From the result, Iron produced the highest values in all the locations followed by Lead in location 1 and 2 , while location 3 was below detection level. Low levels of concentrations were observed for other metals analyzed.

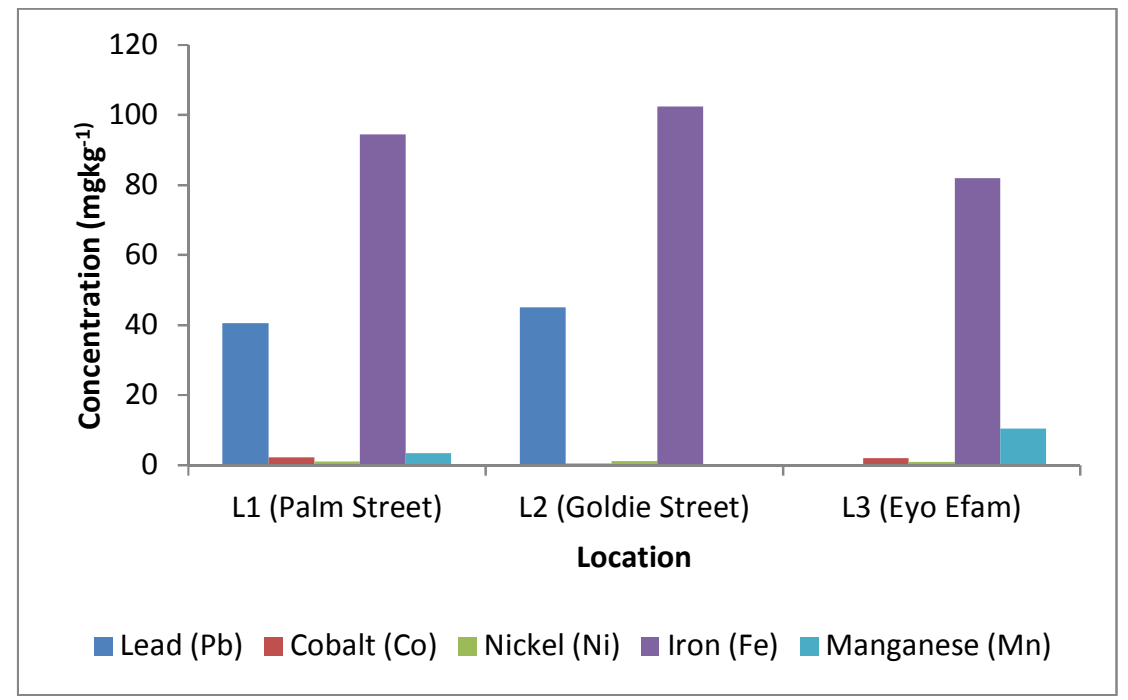

Fig. 2. Mean concentrations and distribution of heavy metals in the three sampling locations

Table 3. Physicochemical characteristics of the soil samples from the three locations

\begin{tabular}{llll}
\hline Parameters/units & Palm street & Goldie street & Eyo Efam street \\
\hline $\mathrm{pH}$ & 8.27 & 7.67 & 7.20 \\
$\mathrm{EC}(\mu \mathrm{s} / \mathrm{cm})$ & 61.3 & 20.6 & 57.9 \\
Nitrate $(\%)$ & 283.5 & 294 & 145 \\
Nitrite $(\%)$ & 0.19 & 0.33 & 0.36 \\
Phosphate $(\mathrm{ppm})$ & 26 & 10 & 26 \\
Calcium $(\mathrm{mg} / \mathrm{g})$ & 0.01 & 0.15 & 0.01 \\
Magnesium $(\mathrm{mg} / \mathrm{g})$ & 0.01 & 0.01 & 0.05 \\
Potassium $(\mathrm{mg} / \mathrm{g})$ & 24 & 21 & 22 \\
\hline \multicolumn{2}{c}{ Key: $(\mu \mathrm{s} / \mathrm{cm})=$ microsiemens per centimeter, \%= percentage, ppm= part per million }
\end{tabular}




\section{DISCUSSION}

Soil microbial communities are a major component of microbial food webs, biogeochemical cycles and energy flow with bacteria as the predominant organism in the microhabitats [8]. Their biodiversity is structured and determined by the temporal and spatial variability of physicochemical and biotic parameters and thus can reflect local environmental conditions $[7,8]$.

This study shows the influence of spent engine oil spill on the microbiological and physiochemical properties of soil. Oilcontaminated soil represents a challenging habitat due to its nature and the presence of some heavy metals. However, microorganisms have adapted to survive in this environment.

In this study, similar genera of bacteria were recovered from oil-contaminated soil samples as total heterotrophic bacteria and hydrocarbon utilizing bacteria. Studies have shown that oil degrading microorganisms are abundant and are not limited to oil producing areas [12]. Soils have been a favorable habitat for the proliferation of microorganisms but the addition of refractory humid substances slows down the activities of these microorganisms, thus giving room to diverse microbial species that have evolved the metabolic capacity to degrade hydrocarbons [4].

The most predominant bacterial genera isolated were Pseudomonas and Bacillus spp. This is in conformity with results obtained by Atlas and Cerniglia [13]. Other prevalent bacterial isolates included Micrococcus spp., Flavobacterium spp., Enterococcus spp., Proteus spp. and Klebsiella spp.

The total heterotrophic bacteria mean count ranged from $1.28 \times 10^{4}$ to $2.58 \times 10^{4} \mathrm{cfu} / \mathrm{g}$. The high counts recorded in sample could be attributed to the myriad of nutrients, high organic matter concentration and other ecological factors that influence the survival of heterotrophic bacteria that play an important role in decomposition and recycling of nutrients. However, the relatively low heterotrophic bacterial counts observed in samples heavily polluted with spent oil can be attributed to the toxic or un-favorable effect of oil contamination [14]. Hydrocarbon utilizing bacteria mean count ranged from $1.94 \times 10^{4}$ to $2.34 \times 10^{4} \mathrm{cfu} / \mathrm{g}$. The presence of these microorganisms can be attributed to the presence of spent oil pollutant in the soil which may have inhibited the growth of heterotrophic bacteria.

Bartha \& Atlas [4] reported that when natural environments are contaminated with pollutants, the indigenous microbial communities are likely to contain microbial populations of different taxonomic characteristics which are capable of degrading the contaminating waste. The ability to isolate high numbers of certain oil degrading microorganisms from oil polluted environment is commonly taken as evidence that these microorganisms are active degraders in the environment.

In automobile workshops, there is a constant change in the soil microorganisms as a result of deliberate spillage of used engine oil. These alter the biomass and ecology of the soil such that both microbial communities and grasses can no longer grow on the soil spots. The colour and texture of the soil are affected; this leads to different microbial flora establishment in an attempt to remedy the petroleum product spillage [15-17]. Although some studies have shown that, oil-polluted soils are dominated by Gram negative bacteria [18-20], the dominant culturable hydrocarbon utilizing bacteria from the samples were made up of gram positive Bacillus and Micrococcus and also gram negative Pseudomonads. The variation in the capacity of the isolates to utilize hydrocarbons could be due to differences in their competence of their crude oil degrading enzyme system while some isolates may be inhibited.

The result of the physicochemical parameters of the soil showed varying electrical conductivity ranges $20.6-61.3 \mu \mathrm{s} / \mathrm{cm}$ and $\mathrm{pH}$ readings ranging from $7.20-8.27$ (neutral to basic) which particularly favors the growth of bacteria. With this, we assumed that bacteria were more involved in the degradation of the oil contaminants. The nitrate and phosphate were higher in value and thus this research work is in tandem with the research work of Akoachere et al. [14].

Microorganisms that are resistant to and grow in metals also play an important role in the biogeochemical cycling of those metal ions. This is an important implication of microbial heavy metal tolerance because the oxidation state of a heavy metal relates to the solubility and toxicity of the metal itself. The range of heavy metals observed in this research can be ascribed to the pollution levels during the period of study. 


\section{CONCLUSION}

The understanding of the influence of different perturbations and the fate of spilled oil in the soil environment is useful in the assessment of the environmental impact of the oil pollutant and its remedial investigation. A general increase in the fertility of the soil after oil pollution occurs but due to the incessant and indiscriminate dumping of spent oil around the study areas, the soil remains polluted and infertile which means that it is rare to find good vegetation around it. The changes in the physicochemical parameters were as a consequence of the buildup in the soil of the products of oil degradation.

The result of this study revealed that the indigenous microbial populations in soils of oil contaminated areas are capable of mineralizing these pollutants in the environment to safe and acceptable levels. From the study it can be concluded that oil-degrading bacteria are abundant in soils contaminated with spent oil.

\section{ACKNOWLEDGEMENT}

I sincerely thank all authors for their immense contributions.

\section{COMPETING INTERESTS}

Authors have declared that no competing interests exist.

\section{REFERENCES}

1. Mandri $T$, Lin J. Isolation and characterization of engine oil degrading indigenous microorganisms in KwaZuluNatal, South Africa. Journal of Biotechnology. 2007;6:23-27.

2. Clemente AR, Anazawa TA, Durrant LR. Biodegradation of polycyclic aromatic hydrocarbons by soil fungi. Brazilian Journal of Microbiology. 2001;32:255-261.

3. Odjeda VJ, Sadiq AO. Effect of spent engine oil on the growth parameters, Chlorophyll and protein levels of Amaranthus hybridus L. The Environmentalist. 2002;22:23-28.

4. Bartha R, Atlas RM. The microbiology of aquatic oil spills. Advances in Applied Microbiology. 2009;22:225-266.

5. Christofis N, Ivshina IB, Kuyukina MS, Philp JC. Biological treatment of crude oil contaminated soil in Russia. In
Contaminated Land and Groundwater: Future Directions ed. Lerner, D.N. and Walton, N.R.G. Engineering Geology Special Publication; 2000.

6. Nilanjana D, Preethy C. Microbial degradation of petroleum hydrocarbon contaminants: An overview. Biotechnology Research International. 2010;11:233-245.

7. Antai SP, Unimke AA, Agbor RB. Assessment of the heterotrophic and crude oil utilizing microorganisms of Imo River Estuary of the Niger Delta mangrove ecosystem. American International Journal of Biology. 2014;2(1):29-42.

8. Unimke AA, Bassey IU, Mmuoegbulam OA, Nseabasi NO. Seasonal implications on the microbiological and physicochemical characteristics of sediments. Imperial Journal of Interdisciplinary Research. 2017;3(1):156-164.

9. APHA. Standard methods for the examination of water and wastewater (20th ed). New York, Ameriacn Water Works Association; 1995.

10. APHA. Standard methods for the examination of water and wastewater. (20th ed). Washington, American Public Health Association; 1998.

11. Holt JG, Krieg NR. Bergey's manual of determinative bacteriology, $9^{\text {th }}$ ed. The Williams \& Wilkins Co., Baltimore; 1994.

12. Okoh Al. Biodegradation alternative in the cleanup of petroleum hydrocarbon pollutants. Biotechnology and Molecular Biology Review. 2006;1:38-50.

13. Atlas RM, Cerniglia CE. Bioremediation of petroleum pollutants. Biological Science. 1999;45:332-350.

14. Akoachere JTK, Akenji TN, Yongabi NF, Nkwelang G, Ndip NR. Lubricating oildegrading bacteria in soils from filling stations and auto-mechanic workshops in Buea, Cameroon: Occurrence and characteristics of isolates. African Journal of Biotechnology. 2008;7:14.

15. Megharaj $M$, Singleton I, McClure NC, Naidu R. Influence of petroleum hydrocarbon contamination on microalgae and microbial activities in a long-term contaminated soil. Archives of Environmental Contamination and Toxicology; 2000.

16. Kaplan CW, Kitts CL. Bacterial succession in a petroleum land treatment unit. Applied Environmental Microbiology. 2004;70: 1777-1786. 
17. Unimke $\mathrm{AA}$, Antai SP, Agbor RB, Nseabasi NO, Agbo BE. Evaluation of seasonal variation in the microbial and heavy metal concentrations of Imo River estuary of The Niger Delta mangrove ecosystem. Advanced Research in Agriculture and Veterinary Science. 2014;1(2):88-94.

18. Bartha R. Biotechnology of petroleum pollutant biodegradation. Microbial Ecology. 2009;12:155-172.
19. Agency for Toxic Substances and Disease Registry (ATSDR). Toxicological profile for total petroleum hydrocarbons (TPH). Atlanta, GA: U.S. Department of Health and Human Services, Public Health Service; 2000.

20. Singer ME, Finnerty WR. Microbial metabolism of straight-chain and branched alkanes. In R. M. Atlas (ed.), Petroleum microbiology". Macmillan Publishing Co., New York; 2004.

(c) 2017 Unimke et al.; This is an Open Access article distributed under the terms of the Creative Commons Attribution License (http://creativecommons.org/licenses/by/4.0), which permits unrestricted use, distribution, and reproduction in any medium, provided the original work is properly cited.

Peer-review history:

The peer review history for this paper can be accessed here:

http://sciencedomain.org/review-history/20114 